Ks. Mirosław S. Wróbel

Verbum Vitae 28 (2015) 213-233

\title{
ŚWIADECTWO JANA CHRZCICIELA W CZWARTEJ EWANGELII
}

\section{The Witness of John the Baptist in the Fourth Gospel}

\begin{abstract}
The present article describes the meaning and function of John the Baptist as the witness to Jesus Christ in the Fourth Gospel. The author shows the activity of John the Baptist in the wider context of the Fourth Gospel, where the various witnesses of God-Father, Son and Holy Spirit all lend a fundamental value for better understanding the existential and theological message of the Fourth Gospel. The article consists of three parts: (1) Terminology and meaning of "witness" in the Fourth Gospel; (2) John the Baptist as the witness in the text of the Fourth Gospel; (3) the theological ramifications of the mission of John the Baptist as the witness of Jesus. In this article the author tries to describe the witness of John the Baptist as not merely historical but still active and current for the people of XXI century.
\end{abstract}

Keywords: John the Baptist, witness, Fourth Gospel

Streszczenie: Niniejszy artykuł stanowi analizę znaczenia i funkcji Jana Chrzciciela jako świadka Jezusa Chrystusa w czwartej Ewangelii. Aktywność Jana Chrzciciela jako prekursora i świadka Mesjasza zostaje ukazana w szerszym kontekście narracji Janowej, w której świadectwo Ojca, świadectwo Syna i świadectwo Ducha Świętego ma fundamentalne znaczenie dla zrozumienia teologicznego i egzystencjalnego orędzia czwartej 
Ewangelii. Artykuł złożony jest z trzech części: 1. Terminologia i znaczenie świadectwa w czwartej Ewangelii; 2. Jan Chrzciciel jako świadek w narracji Ewangelii Janowej; 3. Teologiczne implikacje posłannictwa Jana Chrzciciela jako świadka Chrystusa. W niniejszym artykule autor ukazuje, że świadectwo Jana Chrzciciela nie traci nic na swojej aktualności dla współczesnego człowieka XXI wieku.

Słowa klucze: Jan Chrzciciel, świadectwo, czwarta Ewangelia

Ewangelia Janowa podkreśla rolę Jana Chrzciciela jako świadka Jezusa Chrystusa. Funkcja Jana Chrzciciela w czwartej Ewangelii nie jest ograniczona tylko do udzielania chrztu nad wodami Jordanu oraz wzywania do nawrócenia, lecz do posłannictwa ukierunkowanego na świadectwie o Jezusie Chrystusie. Analiza tego zagadnienia umożliwia głębsze wniknięcie w egzystencjalne i teologiczne przesłanie czwartej Ewangelii ${ }^{1}$. W niniejszym artykule zwrócimy szczególną uwagę na trzy zagadnienia: 1. Terminologia i znaczenie świadectwa w czwartej Ewangelii; 2. Jan Chrzciciel jako świadek w narracji Ewangelii Janowej; 3. Teologiczne implikacje posłannictwa Jana Chrzciciela jako świadka Chrystusa.

\section{Terminologia I ZnaCzenie ŚWiadectwa W CZWARTEJ EWANGELII}

Ewangelia Janowa rozpoczyna się i kończy wzmianką o świadectwie. Na początku, w J 1,7, Jan Chrzciciel jest ukazany jako świadek Swiatłości (,Przyszedł on na świadectwo, aby zaświadczyć o Światłości, by wszyscy

${ }^{1}$ Problematyka ukazująca rolę Jana Chrzciciela jako świadka Jezusa została podjęta we wcześniejszych publikacjach. Zob. de la Potterie, „Jean-Baptiste”, 317-329; Jóźwiak, „Świadectwo”, 414-433; Manns, „Jean-Baptiste”, 97-119; Suski, „Przekaz świadectwa”, 91-102; Kuśmirek, Postannictwo, 118-138; Mickiewicz, Świadkowie, 63-104; Öhler, „Who was John the Baptist?”, 101-118; Backhaus, „Echoes”, 1747-1784. 
uwierzyli przez niego"), a na końcu, w J 21,24, Umiłowany Uczeń występuje w roli świadka (,Ten właśnie uczeń daje świadectwo o tych sprawach i on je opisał. A wiemy, że świadectwo jego jest prawdziwe"). Motyw świadectwa zawarty w narracji Janowej w formie inkluzji wskazuje na istotne znaczenie tego zagadnienia, podkreślając jednocześnie relację pomiędzy Janem Chrzcicielem a Umiłowanym Uczniem ${ }^{2}$. Na znaczenie problematyki świadectwa w czwartej Ewangelii wskazuje także analiza terminologiczna, z której wyraźnie wynika, że ewangelista Jan ma szczególną predylekcję do używania pojęć „świadectwo" i ,świadczyć".

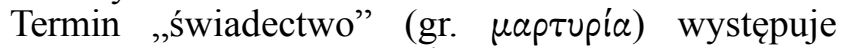
w czwartej Ewangelii 14 razy $^{3}$ i w porównaniu z ewangeliami synoptycznymi jest znacznie częściej używany $^{4}$. Termin ten w narracji czwartej Ewangelii pojawia się już w Prologu, gdzie jest odniesiony do działalności Jana Chrzciciela (J 1,7). Jego częste użycie występuje w kontekście mowy Jezusa po rozmowie z Nikodemem ( $\mathrm{J} 3,11.32 .33$ ), po uzdrowieniu chromego przy sadzawce Betesda (J 5,31.32.34.36) oraz w kontekście burzliwej dyskusji Jezusa na temat swej tożsamości z Jego przeciwnikami (J 8,13,14.17). W rozdziale 3. i 5. w tekstach mówiących o świadectwie jest wzmiankowana explicite osoba Jana Chrzciciela (J 3,22-26; 5,33-35).

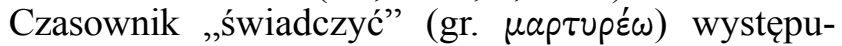
je w czwartej Ewangelii 33 razy $^{5}$ i w porównaniu z synoptykami jego użycie jest o wiele częstsze ${ }^{6}$. Pojęcie to występuje niemal w całej narracji czwartej Ewangelii. W sposób szczególny występuje ono w kontekście świadectwa Jana Chrzciciela (J 1,7.8.15.32.34), mowy Jezusa

${ }^{2}$ Zob. Cothenet, La chaîne; Lee „Witness in the Fourth Gospel”, $1-17$.

${ }^{3} \mathrm{~J} 1,7.19 ; 3,11.32 .33 ; 5,31.32 .34 .36 ; 8,13.14 .17 ; 19,35 ; 21,24$.

${ }^{4} \mathrm{Mt}-0 ; \mathrm{Mk}-3 ; \mathrm{Łk}-1$.

${ }^{5} \mathrm{~J} \quad 1,7.8 .15 .32 .34 ; \quad 2,25 ; \quad 3,11.26 .28 .32 ; \quad 4,39.44 ; \quad 5,31.32$ [x2].33.36.37.39; 7,7; 8,13.14.18 [x2]; 10,25; 12,17; 13,21; 15,26.27; $18,23.37 ; 19,35 ; 21,24$.

${ }^{6} \mathrm{Mt}-1 ; \mathrm{Mk}-0 ; \mathrm{kk}-1$. 
po rozmowie z Nikodemem (J 3,11.26.28.32), mowy Jezusa po uzdrowieniu chromego przy sadzawce Betesda (J 5,31.32.33.36.37.39), w kontekście funkcji Ducha Parakleta (J 15,26.27) oraz w kontekście procesu Jezusa przed Sanhedrynem i przed Piłatem (J 18,23.37).

Świadectwo Jana Chrzciciela należy usytuować w szerszym kontekście czwartej Ewangelii, w której eksponowane jest szczególnie świadectwo Ojca, Syna i Ducha Świętego. W Ewangelii Janowej ważną rolę odgrywa świadectwo Ojca, które jest odniesione do Jezusa. Tekst w J 5,32 podkreśla, że świadectwo Ojca o Jezusie jest prawdziwe. W J 5,37 mowa jest o Ojcu posyłającym Syna i wydającym o Nim świadectwo. Użyty w tym tekście cza-

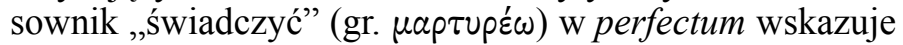
na trwałość i wieczny charakter świadectwa Ojca. Posłanie Syna przez Ojca potwierdzają dzieła dokonywane przez Jezusa (J 5,36) oraz Pisma (J 5,39). Stanowią one istotne świadectwo o Chrystusie jako Słowie wypowiedzianym przez Ojca ${ }^{7}$.

Ewangelista Jan zwraca szczególną uwagę na świadectwo Syna. Jako „Jednorodzony [Syn]"8 i Posłany przez Ojca $^{9}$ objawia On ludzkości tajemnicę Boga Trójjedyne$\mathrm{go}^{10}$. Jezus przebywający w chwale Ojca przed powstaniem świata (J 17,5) jawi się jako Mądrość Boża, która przewodniczy jego powstaniu ${ }^{11}$. Jest On Słowem Boga, przez które wszystko otrzymuje egzystencję ${ }^{12}$. Jezus nie przychodzi sam od siebie, lecz zostaje posłany przez swojego Ojca. Jako „Posłany” zyskuje nie tylko autorytet działania od Boga, ale objawia się jako jedno z Ojcem i jako Ten, który ma uczestnictwo w dziele $\mathrm{Ojca}^{13}$. Syn ma pełne doświadczenie prawdy, o której daje świadectwo (J 3,31-33).

${ }^{7}$ Zob. Giblet, ,Jésus et le Père”, 111-130; Schlosser, Le Dieu de Jésus; Devillers, „Dieu le Père”, 95-116; Wróbel, Who are the Father.

${ }^{8} \mathrm{~J} 1,14.18 ; 3,16.18$.

${ }^{9}$ J $5,23.37 ; 6,44 ; 8,16.18 ; 12,49 ; 14,24$.

${ }^{10} \mathrm{~J} 3,11.32 ; 5,19.30 ; 8,38 ; 15,15$.

${ }^{11}$ Prz 8,22-31; Mdr 9,9; Syr 24,9.

${ }^{12} \mathrm{Iz} 55,10-11 ; \mathrm{J} 1,3.14$.

${ }^{13}$ Zob. Wróbel, „Jezus Janowy jako Objawiciel”, 191-203. 
Przychodzi On na świat po to ,aby dać świadectwo prawdzie" (J 18,37). Świadectwo Jezusa wyraźnie ma charakter autorytatywnego autoobjawienia. Widać to szczególnie przy

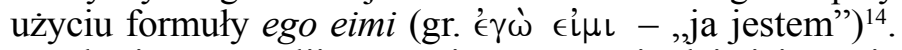
W tekście Ewangelii Janowej można stwierdzić jej użycie $\mathrm{z}$ orzecznikiem i w postaci absolutnej. W pierwszym przypadku formuła ta pojawia się siedmiokrotnie w tekstach, w których Jezus opisuje siebie, podkreślając istotne cechy w odniesieniu do swej funkcji soteriologicznej ${ }^{15}$. W postaci absolutnej formuła ego eimi nie zawiera żadnego orzecznika, lecz występuje w sposób niezależny. W czwartej Ewangelii możemy spotkać jej zastosowanie także w siedmiu tekstach ${ }^{16}$. Używając tej formuły, Jezus w uroczysty spo-

${ }^{14}$ Zob. Ball, ,I Am” in John's Gospel; Williams, I am He; Bauckham, „Monotheism and Christology”, 148-166.

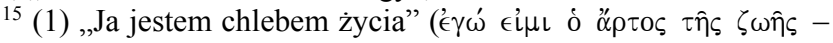

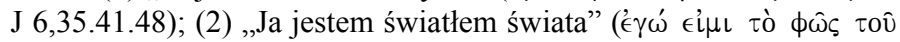

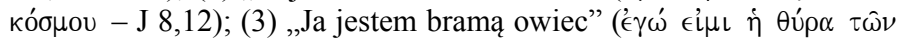

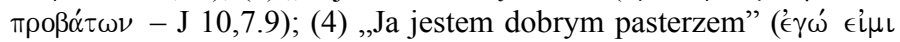

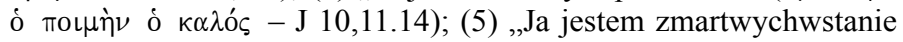

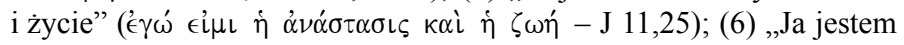

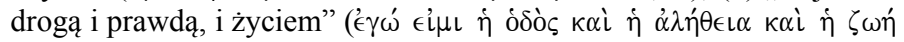

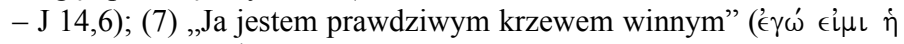
$\ddot{\alpha} \mu \pi \in \lambda 0 \varsigma \dot{\eta} \dot{\alpha} \lambda \eta \theta \iota \nu \grave{\eta}-\mathrm{J} 15,1)$.

${ }^{16}$ (1) ,Ja jestem, który z tobą mówię" ('E $\gamma \omega \dot{~ \epsilon i \mu \iota, ~ o ́ ~} \lambda \alpha \lambda \hat{\omega} \nu$ oo

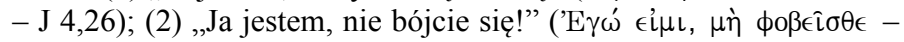
J 6,20); (3) „Jeżeli nie uwierzycie, że ja jestem, pomrzecie w grzechach

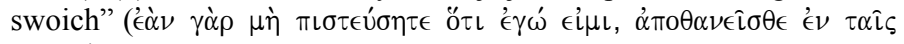
$\dot{\alpha} \mu \alpha \rho \tau i \alpha \iota \varsigma$ i் $\mu \hat{\omega} \nu$ - J 8,24); (4) ,Gdy wywyższycie Syna Człowieczego,

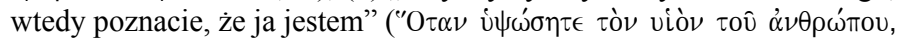

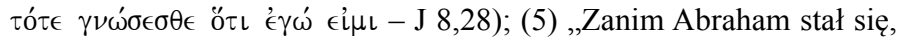

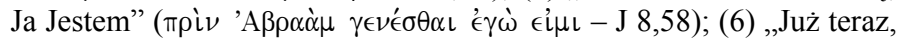
zanim się to stanie, mówię wam, abyście, gdy się stanie, uwierzyli,

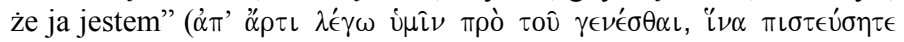

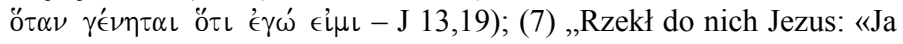
jestem» [...] Skoro więc rzekł do nich: «Ja jestem», cofnęli się i upadli

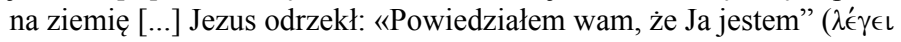

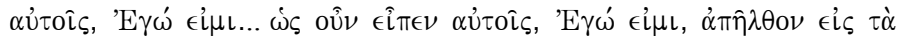

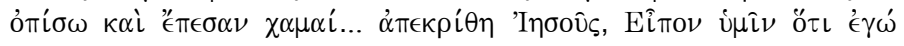

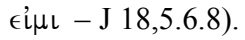


sób świadczy o swojej boskiej godności. Jego świadectwo $\mathrm{z}$ jednej strony spotyka się z przyjęciem ze strony tych, którzy w Niego uwierzyli, z drugiej zaś - z odrzuceniem i sprzeciwem tych, którzy w Niego nie wierzą ${ }^{17}$.

W czwartej Ewangelii ważną funkcję świadka pełni Duch Święty - Paraklet. Znaczenie i funkcja Ducha Świętego jako świadka zostaje ukazana w tekstach pięciu obietnic o Paraklecie ${ }^{18}$. W trzeciej obietnicy (J 15,26-27) wyraźnie sprecyzowana jest funkcja Parakleta jako świadka („On będzie świadczył o Mnie”). W ujęciu Ewangelii Janowej świadectwo to jest skierowane do samych uczniów Jezusa. Specyficznym miejscem dawania tego świadectwa są sumienia uczniów, gdzie żyje i rozwija się wiara w prawdę Jezusa. Wewnętrzne świadectwo Parakleta jest wcześniejsze od świadectwa zewnętrznego uczniów i należy do innego porządku. Głównym celem tego świadectwa nie jest bezpośrednie natchnienie lub wzmocnienie uczniów, by przezwyciężyli prześladowców, lecz zachowanie ich od zagrożenia zewnętrznego, w którym ich wiara zostaje poddana próbie. Widać tu więc wewnętrzny aspekt działania Ducha Parakleta, który związany jest nierozdzielnie z Jego funkcją świadka. Paraklet daje świadectwo Jezusowi tym samym aktem, który będzie prowadził uczniów do całej prawdy interioryzując prawdę Jezusa, oświecając umysły, potwierdzając ich wiarę. W sytuacji niebezpieczeństwa (J 16,1-4) Paraklet działa w sumieniach uczniów, dając świadectwo na korzyść Jezusa. Zewnętrzne świadectwo uczniów ma swą podstawę w innym, wcześniejszym i głębszym świadectwie, jakie Paraklet posłany przez Ojca jako Duch Prawdy i Duch Święty daje o Jezusie w sercach uczniów. Po wydarzeniach paschalnych Duch Paraklet będzie obecny w uczniach jako Nauczyciel, Rzecznik, Obrońca. Pełni więc On funk-

${ }^{17}$ J 8,13 - „Ty sam o sobie wydajesz świadectwo. Świadectwo Twoje nie jest prawdziwe". Zob też: J 3,11.32.

${ }_{18}$ J 14,15-17.26; 15,26-27; 16,7-11.13-15. Zob. Jankowski, Zarys pneumatologii; tenże, „Paraklet”; tenże, Duch Święty; Apostoli, Paraclete; Pastorelli, Le Paraclet; Wróbel, „Dwa dary Ukrzyżowanego”, 31-44. 
cję eschatologiczną. Otacza Jezusa chwałą i doprowadza uczniów - odbiorców daru - do całej i pełnej prawdy.

Powyższa analiza ukazuje, że świadectwo Jana Chrzciciela może być lepiej zrozumiałe w szerszym kontekście świadectwa Ojca, Syna i Ducha Świętego, które ma istotne znaczenia dla egzystencjalnego i teologicznego przesłania czwartej Ewangelii.

\section{JAN Chrzciciel JAKo ŚWIAdeK W NARRACJI EWANGELII JANOWEJ}

Tematyka ukazująca Jana Chrzciciela jako świadka Chrystusa pojawia się aż pięć razy na kartach czwartej Ewangelii ${ }^{19}$. Zapowiada ją już tekst Prologu, który stanowi swoiste preludium do całej narracji Janowej (J 1,6-8.15). Następnie, we fragmencie J 1,19-34 zostaje ukazana postać Jana Chrzciciela w kontekście oczekiwań mesjańskich judaizmu Drugiej Świątyni jako świadka rozpoznającego w Jezusie Mesjasza, Baranka Bożego i Syna Bożego. W J 3,22-36 świadectwo prekursora Jezusa zostaje ukazane na tle sporu o praktyki pokutne Jezusa i jego chrzcielną działalność. W J 5,33-35 sam Jezus określa posłannictwo Jana Chrzciciela jako dawanie świadectwa prawdzie. Po raz ostatni postać Jana Chrzciciela zostaje przywołana w J 10,40-41, gdzie mowa jest o przekonaniu tłumów co do prawdziwości jego świadectwa. We wszystkich tych tekstach podmiotem świadectwa jest postać Jana Chrzciciela. Łączy je także użycie terminów ,świadec-

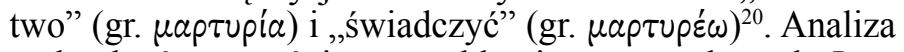
tych tekstów wyraźnie uwypukla pierwszorzędną rolę Jana Chrzciciela jako świadka Jezusa Chrystusa.

${ }^{19}$ (1) J 1,6-8.15; (2) J 1,19-34; (3) J 3,22-36; (4) J 5,33-35; (5) J 10,40-41. Zob. van der Merwe, ,The Historical and Theological”, 267292; Kazmierski, John the Baptist; Joel, „John the Baptist and Jesus”, 179-197.

${ }^{20}$ Zob. Mickiewicz, Świadkowie, 76. 
Już w Prologu (J 1,6-8.15) ewangelista wprowadza osobę Jana Chrzciciela, ukazując w sposób obrazowy jego relację do Jezusa. Jan jest człowiekiem posłanym przez Boga, który ma do wypełnienia ściśle określoną funkcję świadka wobec Jezusa będącego „Słowem” i „Światłem”. Choć sam Jan nie jest „Swiatkem”, to jednak przez jego świadectwo wszyscy mają uwierzyć i zostać przyprowadzeni do Tego, który jest prawdziwą Światłością. Funkcja ta znajduje swoją konkretną realizację w fakcie, że uczniowie Jana staną się pierwszymi uczniami Jezusa (J 1,35-39). Funkcja Jana Chrzciciela jako świadka Jezusa jest akcentowana w wielu miejscach narracji Janowej ${ }^{21}$. Ewangelista podkreśla czasowy wymiar świadectwa Jana Chrzciciela, które ma przygotować świat na przyjęcie świadectwa objawionego przez słowa i czyny Jezusa (J 5,35-36).

W J 1,19-34 Jan Chrzciciel daje najpierw świadectwo o sobie wobec kapłanów i lewitów. Wszelkie wahania i spekulacje ludu na temat przypisywanej mu mesjańskiej tożsamości zostają przez niego jednoznacznie przerwane ${ }^{22}$. Przedstawia on siebie w roli prekursora, który przez wezwanie do nawrócenia i przez chrzest przygotowuje ludzi na spotkanie z Jezusem Chrystusem. Cel i charakter swego posłannictwa formułuje przy użyciu cytatu z proroka Izajasza 40,3. Jan Chrzciciel nazywa siebie „głosem wołającym na pustyni”. Utożsamienie siebie z głosem wskazuje na funkcję Jana Chrzciciela jako kontynuatora misji proroków Starego Testamentu. Mieli oni przygotować lud Izraela na spotkanie z Mesjaszem poprzez przypominanie Słowa Bożego i przemawianie w imieniu Boga. Jan Chrzciciel jako „głos wołający” przyjmuje na siebie zadanie prorockie, aby świadczyć o Tym, któremu nie jest godzien odwiązać rzemyka u sandała $(J$ 1,27). Poprzez bycie głosem i zanurzenie w wodzie Jan Chrzciciel pragnie przygotować lud na przyjście Mesjasza i przyjęcie Jego objawienia (J 1,31). Baptysta daje świadectwo, że oczekiwany Mesjasz - Syn

\footnotetext{
${ }^{21} \mathrm{~J}$ 1,15.29-34.36b; 3,29-36.

${ }^{22}$ Zob. Lach, „Mesjanizm”, 13-24; Goldish, „The Salvation”, 106-
} 118. 
Boży jest w stanie zanurzyć człowieka w Duchu Świę$\operatorname{tym}^{23}$. Zanurzenie to jawi się jako wypełnienie starotestamentalnych obietnic o wylaniu Ducha na końcu czasów ${ }^{24}$. W J 1,29-34 Jan Chrzciciel daje bezpośrednie świadectwo o Jezusie, określając Go mesjańskimi tytułami: Baranek Boga (J 1,29.36), Mesjasz Nieznany (J 1,30-31), Przyjmujący Ducha (J 1,32-33), Syn Boga (J 1,34).

Jan Chrzciciel nazywa Jezusa Barankiem Boga (gr.

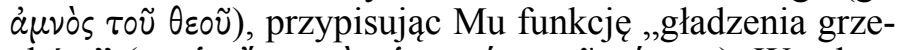

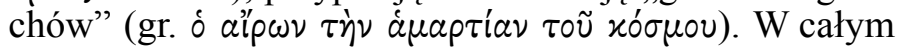
Nowym Testamencie ten chrystologiczny tytuł występuje tylko w świadectwie Jana Chrzciciela (J 1,29.36). Swiadectwo Jana zostaje wzmocnione przez użycie formuły wykrzyknikowej ,oto” (gr. ’ $\delta \varepsilon$ ), która nadaje uroczysty charakter całej wypowiedzi Prekursora Jezusa ${ }^{25}$. Użycie tytułu Baranek Boga nawiązuje do tradycji ofiary baranka paschalnego podczas niewoli egipskiej (Wj 12,21-28). W narracji czwartej Ewangelii w opisie śmierci Jezusa występuje wyraźne nawiązanie do symboliki paschalnej. Według J 19,14 Jezus zostaje skazany na śmierć w dniu przygotowania Paschy około godziny szóstej - dokładnie w czasie, gdy w Świątyni Jerozolimskiej zabijano baranki przeznaczone na ucztę paschalną ${ }^{26}$. W obrazie Baranka Boga można także widzieć cierpiącego Sługę Pana prowadzonego jak baranek na zabicie (Iz 53,7). Funkcja Baranka Boga gładzącego grzechy świata może nawiązywać do opisu funkcji Sługi Pana w tekście proroka Deutero-Izajasza ${ }^{27}$. Tytuł Baranek Boga wypowiadany przez Jana Chrzciciela można także głębiej zrozumieć w kontekście

${ }^{23}$ Zob. Malina, Chrzest Jezusa.

${ }^{24}$ Iz 32,15; 44,3; Ez 36,27; 37,14; 39,29; J1 2,28.

${ }^{25}$ Zob. Witczyk, „Oto Baranek”, 127-149.

${ }^{26}$ Symbolikę paschalną akcentuje także motyw hizopu w J 19,29, nawiązujący do gałązek hizopu, którymi Izraelici kropili odrzwia swych domów (Wj 12,22) oraz motyw braku łamania kości Jezusa wiszącego na krzyżu (J 19,36) - dokładnie jak było w przypadku baranka paschalnego, którego kości nie łamano $(\mathrm{Wj} 12,46)$.

${ }^{27}$ Iz 42,1-9; 49,1-7; 50,4-11; 53,4-7.12. Zob. Bednarz, Jezus Stuga Pańskim); Lemański, „Cierpienia «Sługi Boga»”, 75-101. 
Księgi Apokalipsy, w której postać Baranka odgrywa istotną rolę ${ }^{28}$. W pełnych symboliki i ekspresji obrazach tej księgi krew Baranka uwalnia z grzechów $($ Ap 1,5) i pozwala nabyć dla Boga nowy lud (Ap 5,9). Dzięki swojej krwi Baranek dokonuje ostatecznego zwycięstwa nad wszystkimi wrogami zbawienia ${ }^{29}$.

W swoim świadectwie (J 1,30-31) Jan Chrzciciel nawiązuje do żydowskiej idei „Mesjasza Nieznanego”. Myśl ta może mieć swoją genezę w proroctwie Mojżesza (Pwt $18,15.18)$ zapowiadającego wzbudzenie proroka, który wyzwoli lud z niewoli i objawi prawdę pochodzącą od Boga $^{30}$. W Pwt 18,15.18 można wyróżnić trzy ważne aspekty, które określają istotę proroctwa biblijnego. Po pierwsze, w wyborze i powołaniu proroka inicjatywa należy do Boga. W hebrajskim słowie kum (קום) mieści się posłannictwo, które nie jest tylko wyborem ludzkim, lecz dokonuje się z woli samego Boga ${ }^{31}$. Po drugie, prorok, który jest ustami samego Boga, będzie słuchany przez lud. W jego posłannictwie słowo Boga łączy się ze słowem proroka. Każdy słuchający proroka będzie słuchał jakby samego Boga. Po trzecie, prorok będzie swoją osobą uobecniał, na wzór Mojżesza, samego Boga (wyrażenie ,jak ja” [כמני]) oraz zostanie wzbudzony spośród Izraela - ludu wybranego (wyrażenie ,spośród ciebie, spośród braci twoich” מקרבך [מאחיך]). Zapowiadany prorok jawi się jako Nowy Mojżesz wyzwalający lud z niewoli i obwieszczający prawdę pochodzącą od Boga. Autor czwartej Ewangelii, określając Jezusa jako proroka par excellence, mógł mieć w świadomości tekst proroctwa Mojżesza z Pwt 18,15.18. Powiązanie Proroka z Mesjaszem, na co wskazują paralelne

${ }^{28}$ Motyw Baranka występuje w Apokalipsie aż 29 razy.

29 Zob. Kempiak, „Apokalipsa Janowa”, 195-210.

30 Zob. współczesne ujęcia interpretacyjne dotyczące proroctwa Mojżesza w Pwt 18,15.18 w: Nihan, „Un prophète comme Moïse”, 4376; Achenbach, „A Prophet Like Moses”, 435-458; Atkins, ,Reassessing the Origins", 323-341.

31 Zob. użycie tego terminu na ustanowionych przez Boga: wybawcy (Sdz 3,9.15), króla (1 Krl 14,14), kapłana (1 Sm 2,35), pasterza (Jr 23,4; Ez 34,23). 
teksty, może wskazywać na świadome ukazanie Jezusa jako Mesjasza, w którym wypełniają się wszystkie obietnice Starego Testamentu. Jego wyznawcy są wezwani do przyjęcia Go w wierze i do otwarcia na nowe życie, które jest z tym związane. Ewangelista pragnął przedstawić Jezusa jako Nowego Mojżesza karmiącego lud chlebem z nieba, wyzwalającego z niewoli grzechu i objawiającego mu Boże zamysły 32 . W świadectwie Jana Chrzciciela Jezus zostaje przedstawiony jako „Mesjasz Nieznany”, który stopniowo objawia ludzkości swoją godność mesjańską i tożsamość Syna Bożego.

W J 1,32-33 Jan Chrzciciel daje świadectwo o Duchu, który zstąpił na Jezusa w postaci gołębicy. Jezus w tym świadectwie zostaje ukazany jako „Przyjmujący Ducha”. Baptysta pragnie przedstawić Jezusa jako Mesjasza napełnionego i namaszczonego Duchem Bożym. W Biblii Hebrajskiej termin ruah (רוח) używany na określenie Ducha posiada pierwotne znaczenie - „tchnienie, dech, wiatr”. Duch jest przedstawiany jako siła Boża, moc stwórcza, przenikliwość prorocka. Autorzy natchnieni najczęściej określają Go jako „Ducha Boga” (hebr. רוח אלהים) lub jako „Ducha Świętego" (רוח הקדש. (רש. Określenia te wskazują na szczególne uczestnictwo Ducha w życiu Boga. W Starym Testamencie już od samego początku w akcie stworzenia podkreślana jest obecność Ducha Bożego (Rdz 1,1-2). Teksty starotestamentalne w sposób szczególny akcentują asystencję Ducha Bożego w życiu proroków. Dzięki Duchowi prorok może słuchać Bożych słów, mieć wizję Chwały Bożej oraz przemawiać w imieniu Boga ${ }^{33}$. Pod wpływem Ducha prorocy stają się narzędziami zbawczego działania Boga. Prorocy wiążą bardzo ściśle obecność Ducha z osobą Mesjasza i z czasami eschatologicznymi (Jl 3,1-5). W proroctwie mesjańskim Izajasza Duch Pański ma spocząc na potomku pochodzącym z pnia Jessego, ojca Dawida (Iz 11,1-5). W świadectwie Jana Chrzciciela zstą-

32 Zob. Glasson, Moses.

${ }^{33}$ Ez 2,2; 3,12nn; 8,3; 11,1nn Zob. Léon-Dufour, Stownik teologii, 226-229. 
pienie Ducha na Jezusa ma wyraźnie mesjański charakter. Ukazuje Jezusa jako zapowiadanego Mesjasza - Przyjmującego Ducha, w którego osobie wypełniają się wszystkie zapowiedzi prorockie.

Świadectwo Jana Chrzciciela osiąga swą kulminację w J 1,34, kiedy nazywa Jezusa Synem Boga (gr. ó viós $\tau 0 \tilde{u}$ $\theta \varepsilon o u ̃)$. Świadectwo Jana łączy się tu $\mathrm{z}$ widzeniem mającym charakter oglądu kontemplacji - ,ja ujrzałem i daję świa-

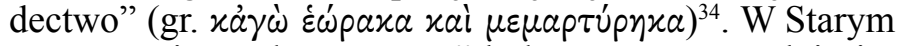
Testamencie tytuł „syn Boga” był stosowany w odniesieniu do narodu wybranego ${ }^{35}$, do szanowanych postaci ludu Izraela $^{36}$, do aniołów ${ }^{37}$ oraz do Króla - Mesjasza ${ }^{38}$. Fakt synostwa Bożego Jezusa zostaje wielokrotnie wyrażony na kartach czwartej Ewangelii przez świadectwo spotykających Go osób: Jana Chrzciciela ${ }^{39}$, Natanaela ${ }^{40}$, Martę ${ }^{41}$. Stanowią oni wzór dla wszystkich członków wspólnoty Janowej, którzy są przez ewangelistę zachęcani do wiary w Jezusa jako Mesjasza i Syna Bożego ${ }^{42}$. W Ewangelii Janowej prawda o synostwie Bożym jest wypowiadana także przez samego Jezusa ${ }^{43}$. Słowa Jana Chrzciciela: „On jest Synem Bożym”, mają charakter świadectwa i wyznania wiary w Jezusa jako Mesjasza i Syna Bożego.

${ }^{34}$ Zob. Mędala, „Kontemplacja Boga”, 37-53.

$35 \mathrm{Wj} 4,22$; Jr 31,9; Oz 11,1.

36 Pwt 14,1; Ps 82,6; Oz 1,10.

37 Hi 1,6.

$381 \mathrm{Krn} 17,13 ;$ Ps 2,7; 89,27.

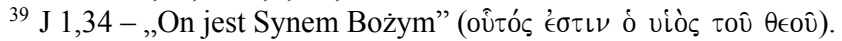

40 J 1,49 - „Rabbi, Ty jesteś Synem Bożym” ("P $\alpha \beta \beta i ́$, où $\epsilon \hat{i}$ ò viò

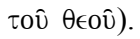

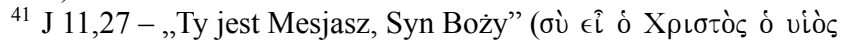

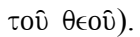

42 J 20,31 - ,[...] abyście wierzyli, że Jezus jest Mesjaszem, Synem Bożym [...]'”.

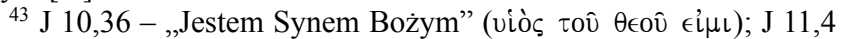
- „Choroba ta nie zmierza ku śmierci, ale ku chwale Bożej, aby dzięki

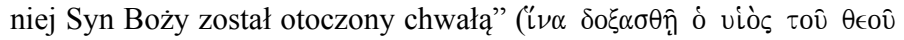
$\delta \iota ' \alpha u ̛ \tau \hat{\varsigma})$. 
W J 3,22-36 zawarte jest świadectwo Jana Chrzciciela, który udziela chrztu w Ainon, w pobliżu Salim. Baptysta wyznaje, że działanie Jezusa jest uwarunkowane „darem z nieba" (J 3,27). Jan Chrzciciel przypomina swoim uczniom, że on sam nie jest Mesjaszem, lecz jest tym, który został przed Nim posłany $(\mathrm{J} 3,28)$. Jako przyjaciel Oblubieńca doznaje on największej radości, słysząc Jego głos. Słowa Jezusa w świadectwie Jana Chrzciciela zostają utożsamione z głosem Oblubieńca. Radości Baptysty, która dochodzi do szczytu, nie przysłania fakt, że wraz ze wzrostem Oblubieńca dochodzi do umniejszenia Jego przyjaciela. W uniżeniu Jana Chrzciciela widać kenozę, która prowadzi do prawdziwego szczęścia (J 3,30). Baptysta podkreśla w swym świadectwie, że Jezus ,przychodzi z nieba" i jest ponad wszystkim (J 3,31). Prekursor Jezusa, patrząc na swoją misję, w pokorze uznaje swą tożsamość jako świadka ,pochodzącego z ziemi”. Jego świadectwo podporządkowane jest świadectwu Jezusa o tym, co widział i słyszał u Ojca w niebie. Świadectwo Jezusa nie jest oparte na świadectwie innych ludzi, lecz pochodzi bezpośrednio „z nieba”. Jan wskazuje, że osoby, które przyjmują świadectwo Jezusa, potwierdzają, że Bóg jest prawdomówny $(\mathrm{J} 3,33)$. Przez wiarę w Jezusa wyznawcy mogą w pełni uczcić Boga Ojca. Jezus - Posłany przez Ojca przekazuje ludzkości Boże Słowa, objawiając w pełni oblicze swego Ojca. Jezus jest nie tylko równy swemu Ojcu, ale w pełni posiada także Ducha otrzymanego przez Ojca (J 3,34). Jan Chrzciciel naucza również o relacji pomiędzy Ojcem i Synem, charakteryzując ją jako relację miłości i pełnego obdarowania (J 3,35). Baptysta mocno podkreśla, że kto wierzy świadectwu Syna, ma życie wieczne, a kto Jemu nie wierzy, ten nie ujrzy życia i doświadczy Bożego gniewu (J 3,36).

W J 5,33-35 sam Jezus odnosi się w swoim nauczaniu do świadectwa Jana, charakteryzując je jako pierwsze i prawdziwe, lecz tylko czasowe. Jan jako pierwszy daje świadectwo prawdzie jednak jego ,płonąca lampa” ma ograniczony czas (J 5,35). Jan Chrzciciel jawi się jako świadek ziemski (doczesny), który prowadzi do Jezusa 
- Światłości nieskończonej. W dalszym kontekście Jezus przywołuje kolejnych świadków. Następnym świadkiem Jezusa, po Janie, są „dzieła”, które Ojciec daje mu do wypełnienia. Cudowne czyny Jezusa świadczą, że jest On posłany przez Ojca $(\mathrm{J} 5,36)$. Trzecim świadkiem jest „słowo” wypowiadane przez Jezusa. Dzięki temu słowu słuchacz może usłyszeć w rzeczywistości słowo samego Boga Ojca (J 5,37-38). Czwartym świadkiem jest „Pismo”, które objawia Jezusa - prawdziwe źródło życia wiecznego (J 5,39-40). W tym kontekście ziemskie świadectwo Jana jawi się jako ściśle podporządkowane niebiańskiemu świadectwu Ojca, Syna i Ducha Świętego objawionemu w „dziełach”, „słowach” i ,pismach”.

Ostatnia wzmianka na temat Jana Chrzciciela pojawia się w J 10,40-41. Są to słowa narratora charakteryzujące świadectwo Jana. Choć Jan nie czyni żadnego cudu, to jednak wszystko, co mówi o Jezusie, jest prawdą. Jego świadectwo prowadzi wielu do wiary w Jezusa z Nazaretu.

\section{Teologiczne implikaCJe POSLANNICTWA Jana Chrzciciela Jako świadka Chrystusa}

Jan Chrzciciel czerpie prawdziwość i moc swego świadectwa ze wspólnoty z Bogiem. Jest on ,człowiekiem posłanym przez Boga" (J 1,6). Świadczy on o Chrystusie - Światłości - a celem jego świadectwa jest to, aby „wszyscy uwierzyli przez niego" (J 1,7). Świadectwo Jana Chrzciciela rozpoczyna się od prawdziwego wyznania wiary $(\mathrm{J} 1,20)$, gdy nazywa On Jezusa: Barankiem Bożym, Mesjaszem, Przyjmującym Ducha, Synem Bożym ${ }^{44}$. Jan w swoim świadectwie ukazuje drogę od widzenia fizycznego do spojrzenia duchowego, które prowadzi go do wyznania wiary: „On jest Synem Bożym” (J 1,34). Drogę tę widać w sposobie patrzenia Jana na Jezusa. Najpierw jest to patrzenie fizyczne, co wyraża użycie czasownika $\beta \lambda \epsilon ́ \pi \omega$ w J 1,29. Przechodzi ono w trwały ogląd wyrażo-

${ }^{44}$ Zob. Mickiewicz, Świadkowie, 87-88. 
ny przez czasownik $\theta \epsilon \alpha \dot{o} \mu \alpha \iota$ w formie perfectum w J 1,32 oraz w kontemplację, dzięki której dostrzega w Jezusie obecność Ducha Świętego - wyrażoną przez czasownik ó $\alpha ́ \omega$ w J 1,34 ${ }^{45}$. Świadectwo Jana Chrzciciela przechodzi drogę od zewnętrznego patrzenia do głębokiej kontemplacji wiary.

W czwartej Ewangelii problematyka wiary jest ściśle połączona $z$ zagadnieniem świadectwa. W narracji Janowej termin ,wierzyć” występuje aż 98 razy. Działalność Jana Chrzciciela jako świadka wzbudzającego wiarę w Jezusa wpisuje się w cel Ewangelii Janowej, którym jest wezwanie do wiary pozwalającej w pełni otworzyć się na Boże objawienie. Cel ten wyraźnie jest podkreślony w świadectwie umiłowanego ucznia (J 19,35) oraz w pierwszym epilogu Ewangelii (J 20,30-31). Wartość wiary uczniów zostaje także podkreślona w słowach jedynego na kartach Ewangelii Janowej błogosławieństwa, które Jezus pozostawia w testamencie swoim uczniom (J 20,29). Jan Chrzciciel jest świadomy, że w osobie Syna posłanego przez Ojca ogniskuje się polemika pomiędzy tymi, którzy Go odrzucają, i tymi, którzy Go przyjmują. Przeciwstawne postawy wobec Jezusa zostają już zapowiedziane w Prologu i są później kontynuowane w całej narracji czwartej Ewangelii. W J 1,11-13 wyraźnie mowa jest o odrzucających i przyjmujących Wcielone Słowo. Odrzucenie daru Ojca prowadzi do zatwardziałości serca i śmierci, zaś jego przyjęcie do pełni wiary i do życia wiecznego. Cała działalność Jana Chrzciciela koncentruje się na świadectwie, które ma prowadzić do prawdziwej Światłości i do życia wiecznego. Wiara w Ewangelii Janowej jest spotkaniem z Chrystusem i przyjęciem Syna Bożego, który przybywa do ludzkości jako Objawiciel Ojca. Wiara związana jest więc ściśle $\mathrm{z}$ dwoma tematami fundamentalnymi dla teologii Janowej: misterium wcielenia oraz misterium objawienia Boga Ojca w Jego Synu Jezusie Chrystusie. Proces wiary uczniów prowadzi do prawdziwego życia w wolności dzieci Bożych

${ }^{45}$ Zob. Mędala, „Kontemplacja Boga”, 45. 
(J 20,31). Życie uczniów w wierze i miłości stanowi, według św. Jana, drogę prowadzącą do domu Ojca (J 14,2-3). Tylko na takiej drodze możliwe jest całkowite otwarcie na Boga oraz doświadczenie głębokiego pokoju i prawdy o życiu wiecznym. Jan Chrzciciel w swoim świadectwie podkreśla dar życia wiecznego dla wierzących. Warunkiem otrzymania życia wiecznego jest przyjęcie w wierze osoby Ojca - Źródła wszelkich darów - i Jego Syna Jezusa Chrystusa ${ }^{46}$. Wiara w Syna Bożego stanowi kryterium podziału na otrzymujących i odrzucających życie wieczne (J 3,36). Jezus precyzuje w swej modlitwie, że życie wieczne polega na poznaniu jedynego, prawdziwego Boga i na poznaniu posłanego przez Niego Jezusa Chrystusa (J 17,3).

W swoim świadectwie Jan Chrzciciel, nazywając Chrystusa Barankiem Bożym, który gładzi grzechy świata $(\mathrm{J} 1,29)$, określa misję Jezusa ${ }^{47}$. Dziełem Baranka jest pokonanie wszelkiego grzechu. Jezus umierający na krzyżu jako Baranek paschalny poprzez swoją ofiarę i śmierć uwalnia świat od grzechu. Ten, który nigdy nie był w niewoli grzechu (J 8,35), zostaje posłany, aby usunąc grzech i otworzyć drzwi raju dla całej ludzkości. Misją Jezusa, na którą wskazuje świadectwo Jana Chrzciciela, jest także chrzest w Duchu Świętym (J 1,33). To posłannictwo Jezusa wpisuje się w nurt zapowiedzi prorockich w Starym Testamencie, które podkreślają wylanie Ducha w czasach eschatologicznych ${ }^{48}$. Owocem zesłania Ducha będzie nowe stworzenie i nowe przymierze Boga z ludźmi. Istota misji Jezusa w świadectwie Janowym zostaje ukazana jako udzielanie ludziom Ducha Bożego, który zstąpił na Niego i znalazł w Nim trwałe mieszkanie. Celem udzielania Ducha jest objawienie Boga, aby ludzie mogli uwierzyć i osiągnąć zbawczy dar życia wiecznego ${ }^{49}$. Przed swoim odejściem Jezus obiecuje uczniom Parakleta, i przekazuje

\footnotetext{
${ }^{46}$ J 3,15b.16b; J 5,24; J 3,15b.16b; J 6,40.47.

${ }^{47}$ Zob. Witczyk, Kościót Syna Bożego, 233-256.

${ }^{48}$ Iz 32,15-18; 44,3-5; J1 3,1-2; Za 12, 10.

${ }^{49} \mathrm{~J} 1,12 ; 3,14-16.34-36 ; 20,31$.
} 
Go im z krzyża (J 19,30) oraz w dniu zmartwychwstania (J 20,22). W ten sposób Duch Święty - Paraklet przebywa we wspólnocie Kościoła, ożywia i uświęca poszczególnych członków wspólnoty i przypomina wszystko, czego Jezus nauczał.

Świadectwo Jana Chrzciciela nie ogranicza się tylko do teraźniejszości, lecz wybiega w przyszłość, aby dać odpowiedź swoim słuchaczom na wszystkie oczekiwania eschatologiczne. Jan Chrzciciel uczy, jak ważną i potrzebną w życiu człowieka jest funkcja świadka. Człowiek nie jest samotną wyspą, lecz jego życie jest zanurzone w doświadczeniu innych ludzi. Poprzez pokorną i cierpliwą postawę ucznia i słuchacza człowiek stopniowo staje się świadkiem dla innych. Im głębiej potrafi przylgnąć do Trójjedynego Boga, tym bardziej doświadcza Jego mocy i zwycięstwa nad grzechem i słabością. Jan Chrzciciel poucza także współczesnych ludzi, że w postawie świadka nigdy nie można zagubić pokory ucznia, ciekawości dziecka i wrażliwości odkrywcy.

\section{BibliogRAFIA}

Achenbach R., ,«A Prophet Like Moses» (Deuteronomy 18,15) - «No Prophet Like Moses» (Deuteronomy 34,10): Some Observations on the Relation Between the Pentateuch and the Latter Prophets", The Pentateuch: International Perspectives on Current Research (red. T.B. Dozeman) (Tübingen 2011) 435-458.

Apostoli A., Paraclete: The Spirit of Truth in the Church (Cincinnati 2005).

Atkins J.D., ,Reassessing the Origins of Deuteronomic Prophecy: Early Moses Traditions in Deuteronomy 18,15-22", Bulletin for Biblical Research 23/3 (2013) 323-341.

Backhaus K., ,Echoes from the Wilderness: The Historical John the Baptist", Handbook for the Study of the Historical Jesus (red. T. Holmén - S.E. Porter) (Leiden 2011) II, 1747-1784. 
Bauckham R., „Monotheism and Christology in the Gospel of John", Contours of Christology in the New Testament (red.

R.N. Longenecker) (Cambridge 2005) 148-166.

Ball D.M., „I Am” in John's Gospel: Literary Function, Background and Theological Implications (Journal for the Study of the New Testament Supplement Series 124; Sheffield 1996).

Bednarz M., Jezus Stuga Pańskim wedtug Nowego Testamentu (Tarnów 2001).

Cothenet É., La chaîne des témoins dans l'évangile de Jean: de Jean-Baptiste au disciple bien-aimé (Paris 2005).

Devillers L., „Dieu le Père dans le quatrième évangile”, Roczniki Teologiczne 52 (2005) 95-116.

Giblet J., „Jésus et le Père dans le IV évangile”, L'Évangile de Jean (red. F.M. Braun) (Paris 1958) 111-130.

Glasson G.T., Moses in the Fourth Gospel (Studies in Biblical Theology 40; London 1963).

Goldish M., „The Salvation of Jesus and Jewish Messiahs”, Jesus among the Jews. Representation and Thought (red. N. Stahl) (Routledge Jewish Studies Series; New York 2012) 106-118.

Harstin S., Moses as a Character in the Fourth Gospel: A Study of Ancient Reading Techniques (Journal for the Study of the New Testament Supplement Series 229; Sheffield 2002). Jankowski A., Zarys pneumatologii Nowego Testamentu (Kraków 1982).

Jankowski A., „Paraklet”, Egzegeza Ewangelii św. Jana (red. F. Gryglewicz) (Lublin 1992).

Jankowski A., Duch Święty dokonawca zbawienia. Nowy Testament o posłannictwie eschatologicznym Ducha Świętego (Kraków 2003).

Joel M., ,John the Baptist and Jesus”, When Judaism and Christianity Began. I. Christianity in the Beginning. Essays in Memory of Anthony J. Saldarini (red. A.J. Avery-Peck et al.) (Supplements to the Journal for the Study of Judaism; Leiden 2004) 179-197.

Jóźwiak F., „Świadectwo Jana Chrzciciela o Jezusie Chrystusie w świetle IV Ewangelii”, Ateneum Kapłańskie 81 (1973) 414-433. 
Kazmierski C.R., John the Baptist - Prophet and Evangelist (Zacchaeus Studies: New Testament; Collegeville 1996).

Kempiak R., ,Apokalipsa Janowa i jej przesłanie na temat wolności”, Apokaliptyka wczesnego judaizmu i chrześcijaństwa (red. M.S. Wróbel) (Analecta Biblica Lublinensia 6; Lublin 2010) 195-210.

Kuśmirek A., Posłannictwo Jezusa Chrystusa wedtug czwartej Ewangelii (Warszawa 2003).

la Potterie I. de, „Jean-Baptiste et Jésus témoins de la vérité d'après le IVe Évangile", Le témoignage (red. E. Castelli) (Paris 1972) 317-329.

Lee D.A., ,Witness in the Fourth Gospel: John the Baptist and the Beloved Disciple as Counterparts", Australian Biblical Review 61 (2013) 1-17.

Lemański J., „Cierpienia «Sługi Boga» typem zbawczej pasji Chrystusa", Verbum Vitae 1 (2002) 75-101.

Léon-Dufour X. (red.), Słownik teologii biblijnej (Poznań 1990). Łach S., „Mesjanizm we współczesnej biblistyce”, Mesjasz w biblijnej historii zbawienia (red. S. Łach - M. Filipiak) (Lublin 1974) 13-24.

Manns F., „Jean-Baptiste, témoin de Jésus d'après le quatrième Évangile", Studia Hierosolymitana (red. G.C. Bottini) (Jerusalem 1982) III, 97-119.

Mędala S., „Kontemplacja Boga w Jezusie według czwartej Ewangelii”, Collectanea Theologica 70 (2000) 37-53.

Mickiewicz F., Świadkowie zbawczego posłannictwa oraz mesjańskiej i boskiej godności Jezusa w pismach św. Łukasza $i s ́$ w. Jana (Ząbki 2003).

Nihan C., ,«Un prophète comme Moïse» (Deutéronome 18,15): genèse et relectures d'une construction deutéronomiste", La construction de la figure de Mö̈se (red. T. Römer) (Paris 2007) 43-76.

Öhler M., ,Who was John the Baptist?: From John 1,19-28 to Heracleon”, „For it is written”: essays on the function of Scripture in Early Judaism and Christianity (red. J. Dochhorn) (Early Christianity in the Contet of Antiquity 12; Frankfurt am Main 2011) 101-118.

Pastorelli D., Le Paraclet dans le corpus johannique (BZNW 142; Berlin 2006). 
Schlosser J., Le Dieu de Jésus. Étude exégétique (Paris 1987). Suski A., „Przekaz świadectwa Jana Chrzciciela w czwartej Ewangelii”, Collectanea Theologica 71/1 (2001) 91-102.

Van Der Merwe D.G., ,The Historical and Theological Significance of John the Baptist as He Is Portrayed in John 1", Neotestamentica 33 (1999) 267-292.

Williams C.H., I am He. The Interpretation of ,Ani Hu” in Jewish and Early Christian Literature (WUNT II/113; Tübingen 2000).

Witczyk H., „ «Oto Baranek Boży zwyciężający grzech świata»

(J 1,29). Eucharystia a «grzech świata»", Biblia o Eucharystii (red. S. Szymik) (Lublin 1997) 127-149.

Witczyk H., Kościół Syna Bożego. Studium eklezjologii czwartej Ewangelii (Kielce 2012).

Wróbel M.S., Who are the Father and his Children in Jn 8:44?

The Literary, Historical and Theological Analysis of Jn 8:44 and its Context (Paris 2005).

Wróbel M.S., „Dwa dary Ukrzyżowanego: Maryja i Duch (J 19,25-37)", Salvatoris Mater 38 (2008) 31-44.

Wróbel M.S., „Jezus Janowy jako Objawiciel oblicza Ojca”, Verbum Vitae 20 (2011) 191-203.

\section{Ks. Mirosław Stanisław Wróbel \\ Aleje Ractawickie 14 \\ 20-950 Lublin \\ miwrobel@kul.lublin.pl}

Ks. MirosŁaW StanisŁaW Wróbel, profesor nauk teologicznych, doktor nauk biblijnych École Biblique w Jerozolimie, kierownik Katedry Filologii Biblijnej i Literatury Międzytestamentalnej w Instytucie Nauk Biblijnych KUL, autor licznych monografii i artykułów naukowych podejmujących różnorodną problematykę związaną z Ewangelią Janową, relacją pomiędzy judaizmem i chrześcijaństwem oraz źródłami judaizmu okresu Drugiej Świątyni i judaizmu rabinicznego. Wybrane publikacje książkowe: Synagoga a rodzacy się Kościól. Studium egzegetyczno-teologiczne Czwartej Ewangelii (Kielce 2002); Antyju- 
daizm a Ewangelia wedtug św. Jana. Nowe spojrzenie na relacje czwartej Ewangelii do judaizmu (Lublin 2005); Who are the Father and his Children in Jn 8:44? The Literary, Historical and Theological Analysis of Jn 8:44 and its Context (Paris 2005); Jezus i Jego wyznawcy w Talmudzie. Analiza tekstologiczna, historyczna i socjologiczna (Lublin 2013); Targum Neofiti 1. Księga Rodzaju. Tekst aramejski - przektad - aparat krytyczny - przypisy (Biblia Aramejska) (Lublin 2014). Członek Stowarzyszenia Biblistów Polskich, Polskiego Towarzystwa Studiów Żydowskich, Associazione ex-alumni del Pontificio Istituto Biblico, Society of Biblical Literature, Catholic Biblical Association. 
